Askild H. Nilsen

\title{
Available outdoor space and competing needs in public kindergartens in Oslo
}

\begin{abstract}
To be able to plan a diverse and flexible environment in kindergartens for children from 1 to 5 years of age, available and adequate space is needed, preferably an open and coherent space adaptable to change. Hence, size itself is a factor to control and regulate to ensure that children's needs are met. The aim of this study was to investigate how the utilization of outdoor space responded to changes in applied norms and law over time. The hypothesis was that needs for space of a more administrative nature, such as parking, have been prioritized over play area. To test this hypothesis, 201 public kindergartens in Oslo's outer city that offer full-day service were studied. The main findings were that the gross size of kindergartens in Oslo decreased by $12.6 \mathrm{~m}^{2}$ per child for those built after 2006 compared to those built before 1975, due to legal changes in these time intervals, and that play space per child constituted more than half of this decrease. In the same time period, the reduction in space for parking and roads on the premises decreased by only 1.6\%. This finding suggests that norms founded in laws win the battle over space, even if this indirectly compromises the meeting of children's needs for an adequate outdoor play area.
\end{abstract}

Keywords: children's right to play, outdoor play area, parking, space discourse

\section{Introduction}

It is well-known that free play is important for many aspects of children's development. The possibility to play in a spacious outdoor environment offers benefits that cannot be achieved solely through indoor play, because children are more motivated to engage in physical activities and play more intensively in the outdoor environment due to a greater freedom of movement (Giske, Tjensvoll, \& Dyrstad, 2010). Outdoor play is characterized by the possibility for spontaneous stimulation of all senses and balance, and encourages children to engage in vigorous, chaotic and free play including running, climbing and chasing, but also offers the possibility for more quiet fantasy play (Dahlgren, Sjölander, Strid, \& Szczepanski, 2007). According to Grindberg \& Langlo (2000: 15) planners also have a duty to provide good possibilities for physical activity in the kindergarten, while it is grounded in children's needs for movement and the growing understanding of how important multiple motor experiences are for their complete development (in Norway, the word "kindergarten" describes a pedagogic service for children from 1 to 5 years of age and is therefore used in this article).

Play provides opportunities for children to learn social interaction, and all parents aspire for their children to be successful in these interactions. This success is a measure of the children's social well-being, and is marked by their ability to develop and sustain friendships and to cooperate, lead and follow. Unstructured active play with others, including parents, siblings and peers, is a major opportunity to cultivate social skills. Free play has the potential to improve many aspects of emotional well-being, for instance minimizing anxiety, depression, aggression and sleep problems (Burdette \& Whitaker, 2005). If the environment prevents multiple motor experiences this can lead to physiological immaturity, retarded growth and weight gain, and delayed bodily emotional and mental development (Sandborgh, 1982).

When planning outdoor environment for children one should bear in mind that children have various so-called "intelligence profiles", including aspects such as language, 
musicality, social skills, logic and self-visualization, both physically and mentally. Some of these characteristics require open space for games full of action, while others need enclosed space for a slower rhythm (Gardner, 1998). To be able to evolve these intelligence profiles, the outdoor environment needs to be stimulating and rich in variation and diversity (Svedberg \& Zaar, 1998). Children need the possibility for movement, hiding places, curiosity and exploration (Ellneby, 1999); such activities need a fairly large space to be performed.

In recent years a philosophy of thinking around children's learning called "Reggio Emilia" has been widely applied in relation to policy and practice in kindergartens in Sweden and Norway (Kjørholt \& Seland, 2012). This philosophy regards the physical place and design of the kindergarten as "the third pedagogue", lending an underlying expectation of thoughtful management of outdoor areas. Since 1995 in Norway, there has been a trend to construct and design kindergartens physically to be an appropriate and flexible place for children (Kjørholt \& Tingstad, 2007). Outdoor flexibility requires space set aside for play only, but not overly designed or filled with constructions or play equipment restricting children's creativity.

To be able to plan such a diverse and flexible environment and literally prepare the ground for multiple activities, available and adequate space is needed, preferably an open and coherent space adaptable to change. Hence, size itself could therefore be suggested to be a factor to control and regulate to ensure that children's needs are met. The effect of legal regulations regarding outdoor space for children in kindergartens has not been thoroughly investigated in any country (Huntsman, 2008; Thorén, Guttu, \& Pløger, 2000), but a recent study (Nilsen \& Hägerhäll, 2012) found that play space per child fell significantly when norms for minimum play space were no longer part of Norwegian legislation. This suggests that legally binding norms are important in protecting space requirements for play areas in kindergartens.

There are also no regulations regarding the size per child of the play area in school yards. It has been suggested to set a minimum requirement at $50 \mathrm{~m}^{2}$ per pupil (Thorén, 2003), because the area, along with the equipment, for activities and play is important. Generally, when planning, required quantitative and technical norms regarding noise, number of parking places, road standards and fire safety are most likely to win the battle over space (Thorén, et al., 2000). Studies of outdoor space in bigger cities suggest that although municipalities have their own guidelines regarding the Planning and Building Act $\S$ 69.3, with norms for playgrounds, this alone has not been sufficient for securing quality in the outdoor play area (Schmidt, 2008); in this context quality also includes play area size.

The reduction of outdoor play space may hinder children from exercising their right to play according to the UN Convention on the Rights of the Child (UNCRC) Article 12, "Respect for the views of the child" (UN, 2009). In the Norwegian legal response to the UNCRC, the Kindergarten Act 2005-06-17 no. 64, Section 3, declares children's right to participate and express their views (MER, 2006), something also argued for by researchers in the area who claim that play is children's way of participating and expressing views (Bae, 2010). Having outdoor playtime and room to do so is acknowledged as fundamental to children's well-being and development, and as a need and a right (Mackett \& Paskins, 2008; OECD Directorate of Education, 2006; Powell, 2009).

Decreasing space is a growing problem, especially in big cities. A key feature in the past 30 years is that former large, continuous natural areas have been highly reduced and urban areas have become more cultured and gray (Nyhuus, 1996), and hence today there is increasing competition over various functions or needs for space. The dynamic discourse over which variables to legally encourage or suppress is constantly scrutinized in a healthy society, and most countries legitimate or prioritize the functions by implementing laws and norms. In any public development, the planners will have to relate to both non-negotiable variables set 
down by law and those that are negotiable and for planners to adapt in accordance with local conditions. New public kindergarten projects are relatively small-scale compared to most public developments, but undergo the same official planning routines and planning hierarchy, like any other new project governed by public officials. The projects are clearly defined, and the total time between initiated planning to finished product rarely exceeds two years. This makes public kindergartens ideal for investigating the result of changing requirements by law.

The change in the national jurisdiction to direct more responsibility to local involved planners and builders is part of a larger trend called New Public Management (NPM) (Sager, 2009). According to Sager, the typical Nordic planners are much closer to Communicative Planning Theory (CPT) than to NPM in that they want to plan and understand their role, often causing tensions among planners; in this case, landscape architects who plan the outdoor environment in kindergartens. There might be tension due to an ideal concerning planning the best possible outdoor space for children's needs, while this goal is not directly supported by the laws that must be applied. This possible tension is the theoretical base for this study, the aim of which was to investigate how space distribution has influenced the utilization of the available outdoor space in public kindergartens, especially the play area. The hypothesis was that needs other than those for play area have been increasingly granted more outdoor space, particularly those that are better protected by laws and norms, causing a reduction in the space available for outdoor play.

There are several important factors here. Firstly, the impact of cars on urban areas, generally from the 1960s until today, is fundamental. This also has a particular impact on kindergartens because there is an increasing trend of parents driving their children to school and kindergarten, which requires more designated space for access and parking on the premises. According to the current regulations, two to six car parking places are required per ten employees in kindergartens in the outer city of Oslo (Plan- og bygningsetaten, 2004). The need for guest parking is evaluated if necessary. Parking is required to be on the property or on a neighbouring property with legal confinements. The requirement for parking leads not only to a need for parking space, but also to a need to manoeuvre space, ensure access to an exit road, and offer the possibility to obtain a visual overview of roads, thus affecting the positioning and size of fences, buildings, trees and more. The use of bicycles has also increased, and bicycle parking received its own norms in 2004; today, two places are required per ten employees (Plan- og bygningsetaten, 2004). When building new public kindergartens today the proprietor, Municipal Undertaking for Social Service, normally only asks for the minimum required number of parking spaces for both cars and bikes. Exception from these requirements is granted if the kindergarten is considered temporary.

Secondly, cars also contribute to noise, which can be a problem especially for outdoor activities. Guidelines setting limits for decibel levels both outdoors and indoors for example housing, schools or kindergartens was implemented in 2005 (Statens forurensingstilsyn, 2005). New kindergartens are only allowed to be located in areas with an annual average of less than 59 decibels in the outdoor play area. If the location experiences up to 64 decibels a new kindergarten may be accepted, but only if measures are implemented to reach accepted decibel levels of noise, usually involving barriers to protect the area from traffic noise.

Other space requiring variables in kindergartens include space between buildings and property boundary, space required to be fenced out in defined distance to roads according to the zoning plan, space fenced out for safety reasons, distance from power lines and antennae, space for waste storage, and space to allow access for fire engines.

In 2005, the Norwegian government ambitiously promised full coverage of kindergarten places by 2007. As Oslo was in critical need of new kindergarten places in 2005 and available properties were scarce, pressure was added to every new kindergarten project to build for the maximum possible number of places. In February 2008 the city still had over 
6,100 children on waiting lists (Dregelid, 2008). As a result, the maximum exploitation of every available property was always a must; there was thus increased tension between different needs. In this situation, the landscape architect and other involved planners had to prioritize when determining the space distribution on the kindergarten premises. Some spacerequiring variables were non-negotiable as they were based on legal confinements, and therefore had to be prioritized over others. Other variables were negotiable, however. The result of this tension has been investigated in this study by measuring the change in utilization of available area in kindergartens over time.

\section{Materials and Methods Selection of kindergartens}

To investigate how available space in kindergartens became limited, Oslo, the capital of Norway, was chosen. Public kindergartens in Oslo are plenty, with a great number of locations owned by one proprietor obliged to implement updated laws and political decisions (Municipal Undertaking for Social Service Buildings). With a focus on contemporary events but with no need to control behavioural events, the method case study is relevant (Yin, 2009: 8). A case study of public kindergartens in one city, in this situation a capital city, including all public kindergartens can provide reliable and useful information (Flyvbjerg, 2006).

Oslo is divided into 15 boroughs. The city centre with boroughs 1-5 are designated as inner city due to their building density, while borough 6-15 are designated as outer city, and the requirements for administrating and building in the two city parts are different. The reason for looking at the outer city is that more variables are competing over available gross size at each kindergarten premises. The outer city is less densely built than the inner city, and kindergartens have been planned as an integrated part of the city expansions, in contrast to the inner city, where kindergartens have more often been established wherever possible within the existing city fabric. In the inner city, the competition over available space has led to different solutions than in the outer city: the inner city does not require parking on the premises, buildings are allowed along the perimeter of the property, and a distance between individual buildings is not required. Paradoxically, this results in fewer variables in the space rival discourse in the inner city than the outer city.

Only kindergarten locations offering a full-day service were investigated based on the presumption that outdoor facilities are especially important when children stay in day care for the entire day. In June 2010 there were 328 public kindergarten locations in Oslo offering a full-day service (opening hours 07.30-17.00) for children aged one to five years, serving approximately 23,648 children. This investigation looks only at the outer city (due to more competing variables as described earlier), with 227 kindergartens offering a full-day service. Twenty-six kindergartens were excluded as they were part of greater properties and not the single establishment on the premises. The final sample hence comprised 201 public kindergartens with 12,001 places for children.

\section{Procedure}

First, a review of the legal requirements planners must comply with was performed. This included requirements for planning and management of the construction of public kindergartens in Oslo. Only laws related to space-demanding requirements in the outdoor environment were included in the research. Legal documents were accessed through the national database, www.lovdata.no.

Second, a retrospective investigation was performed on the space management and space competition in existing kindergartens. The following data were collected: address of each kindergarten location, building year, year of latest change of building, and number of places at each site. The following data were calculated from maps of each kindergarten: 
1. Gross size - of the total property

2. Footprint - of buildings on the property

3. Play space - size of outdoor play area per child over time

To be able to investigate how other space requirements affect play space, the play space and footprint of the building were subtracted from the gross size, resulting in what will from here on be called administrative space. This administrative space was then classified, according to use, into the following variables:

1. Parking and access - space for parking, manoeuvring and gaining access outside the play area.

2. Corridors - space between building and property boundary. Most often a result of the zoning plan requiring a minimum of eight meters between buildings to prevent fire hazard. Often not used as play area due to difficulties monitoring the area.

3. Roadside - space required as distance to a road according to the zoning plan, fenced out from practical use or play area.

4. Safety - space fenced out due to possible safety issues, usually within two categories: (i) physical reason: space with steep terrain, retaining walls and fire stairs are often made unavailable to children by fencing out the space; (ii) social reason: space which is visually hidden or difficult for employees to monitor is often made unavailable to children by fencing out the space.

5. Unused - space on the property fenced out from practical use or play area. This space seemed to have no designated function and no clear reason for not being used.

There are more space-demanding variables that were not tested in this study as individual variables, due to scarce representation or joint use with other variables listed above. These variables are:

1. Radiation protection (distance from high-voltage power line or cell phone antenna)

2. Waste storage (space for bins)

3. Noise protection (usually barrier to protect from traffic noise)

4. Fire protection (space to allow access for fire engine)

The data for the discussed variables were all collected or calculated on the basis of national databases. The primary source of space information was the digital map provided by the Norwegian Mapping Authority in Hønefoss, Norway, accessed via Internet at www.finn.no. Supplementary information was obtained from various digital photo services covering the whole city, such as aerial photos from March and April 2009 and a 3D aerial photo service provided by Norkart Geoservice in Sandvika, Norway, accessed through www.gulesider.no. Another useful tool was a street photo surround service based on photos taken during summer 2008 and 2009, provided by Google maps. By searching addresses and using the available digital measuring tools in the maps or photos in combination with aerial photos, it was possible to measure and calculate space. When in doubt, it was possible to use the $3 \mathrm{D}$ aerial photo service and the street photo surround service to better understand the situation.

All full-day operating public kindergartens in Oslo in June 2010 were listed on the website of the proprietor Municipal Undertaking for Social Service Buildings in Oslo at 
www.omsorgsbygg.oslo.kommune.no, where information on address and number of places and employees was presented. Most kindergartens also had a unique web page giving information on their address, key personnel, and usually the number of children accepted at the premises. Due to some inconsistency in the information provided online, it was necessary to contact some kindergartens to obtain missing data. To understand the complexity (often, more than one property made up one location), affirm the size of each property and find the building year, the official information on properties provided by Norwegian property information AS, accessed through www.eiendomsinfo.no, was used.

A previous study by Nilsen \& Hägerhäll (2012) found a significant difference in size of play area in relation to when a norm of $24 \mathrm{~m} 2$ of play area was present from 1975 to 2006. Therefore, the same time interval is applied here to possibly find other related effects on space distribution of laws and norms over time.

\section{Statistics}

Pearson's Chi-Square 2-tailed test was used for the statistical evaluation of results using PASW statistical software version 17.0 (IBM Corp., Armonk NY, USA). Chi-square tests are commonly used to study the difference between proportions. In this study, the proportions of kindergartens that comply with the criteria are compared, e.g., kindergartens built during different time periods. A p-value less than 0.05 shows statistically significant difference between kindergartens built during these time periods. A p-value above 0.05 indicates that one may be able to attribute the observed differences to chance.

\section{Results}

The 201 studied kindergartens were built over a long time span: 39 were built before 1975 (2,133 places), 99 between 1976 and 2006 (5,538 places) and 63 after 2006 (4,330 places). The decades in which each kindergarten building was built are presented in Figure 1.

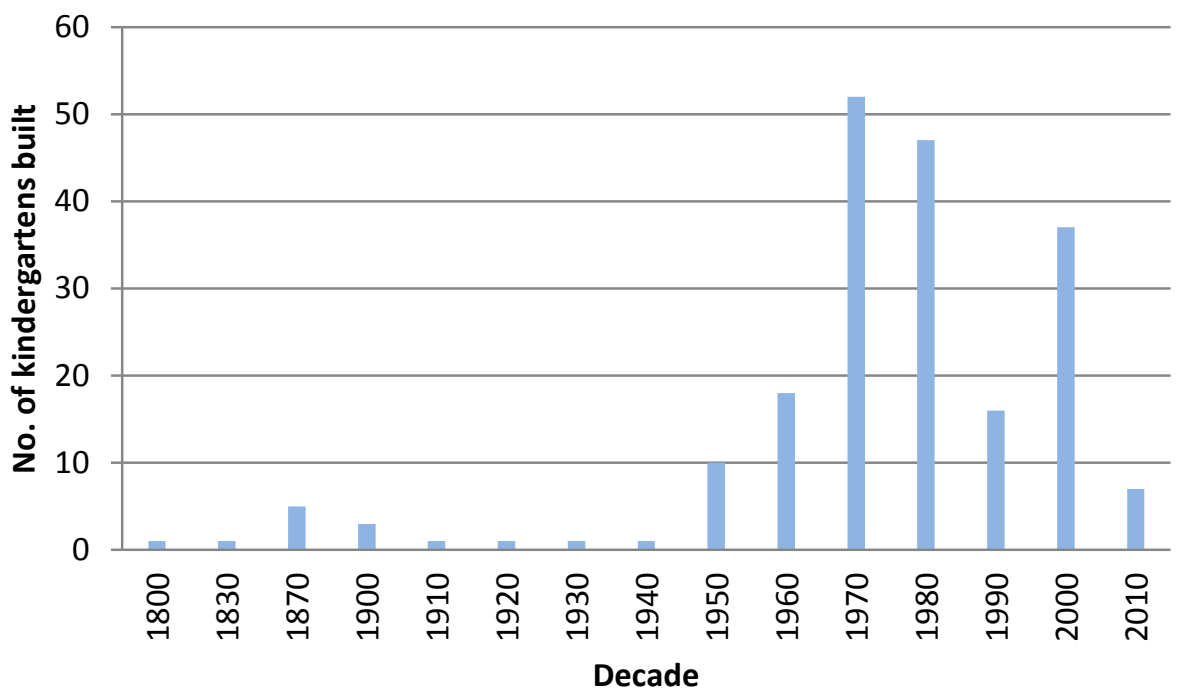

Figure 1. Number of kindergartens built per decade.

Buildings built before 1940 were rarely originally built for the purpose of being a kindergarten. A total of $49.3 \%$ of the kindergartens (99 of 201) were built in the 1970s and 1980s, while about 22\% were built in 2000 and 2010 (44 of 201). The two pronounced periods in which most kindergartens were built correspond with a political focus on building kindergartens. 
The space distribution in kindergartens in three studied time periods is presented in Table 1. As shown in the table, the average gross size of property per child was reduced by about 12 $\mathrm{m}^{2}$ in kindergartens built after 2006 compared to those built before 1975 . The reduction in the variable "Gross size" has directly influenced the variable "Footprint of building", due to how zoning limits the maximum exploitation. The largest reduction in space was observed for "Play area", comprising about $54 \%$ of the reduction in area. In comparison, only a small proportion of the space reduction was related to "Parking and access", less than $2 \%$ of the total reduced area. The variables "Unused", "Corridors" and "Roadside" were also reduced, meaning a more efficient distribution of available space after 2006. "Safety" required very little space per child in general, and were almost unchanged over time.

Table 1. Utilization of available area in kindergartens presented as average $\mathrm{m}^{2}$ per child

\begin{tabular}{|c|c|c|c|c|c|c|c|c|}
\hline Building year & $\begin{array}{c}\text { Gross } \\
\text { size of } \\
\text { property } \\
\text { per child } \\
\left(\mathrm{m}^{2}\right)\end{array}$ & $\begin{array}{l}\text { Footprint } \\
\text { of building } \\
\text { per child } \\
\left(\mathrm{m}^{2}\right)\end{array}$ & $\begin{array}{l}\text { Play } \\
\text { space per } \\
\text { child } \\
\left(\mathrm{m}^{2}\right)\end{array}$ & $\begin{array}{l}\text { Unused } \\
\text { area } \\
\text { per child } \\
\left(\mathrm{m}^{2}\right)\end{array}$ & $\begin{array}{c}\text { Corridors } \\
\text { per child } \\
\left(\mathrm{m}^{2}\right)\end{array}$ & $\begin{array}{l}\text { Roadside } \\
\text { area } \\
\text { per child } \\
\left(\mathrm{m}^{2}\right)\end{array}$ & $\begin{array}{c}\text { Parking and } \\
\text { access } \\
\text { per child } \\
\left(\mathrm{m}^{2}\right)\end{array}$ & $\begin{array}{l}\text { Safety } \\
\text { area } \\
\text { per child } \\
\left(\mathrm{m}^{2}\right)\end{array}$ \\
\hline Before 1975 & 53.81 & 9.37 & 33.07 & 3.33 & 3.14 & 0.91 & 3.63 & 0.36 \\
\hline $1975-2006$ & 49.38 & 9.02 & 31.02 & 3.05 & 1.50 & 0.42 & 3.37 & 1.00 \\
\hline After 2006 & 41.75 & 7.87 & 26.60 & 1.58 & 1.75 & 0.23 & 3.44 & 0.29 \\
\hline $\begin{array}{l}\text { Space reduction } \\
\text { after } 2006 \\
\text { compared to } \\
\text { before } 1975\end{array}$ & 12.06 & 1.50 & 6.47 & 1.75 & 1.39 & 0.68 & 0.20 & 0.07 \\
\hline $\begin{array}{l}\text { Per cent } \\
\text { of total space } \\
\text { reduction }\end{array}$ & 100.0 & 12.4 & 53.7 & 14.5 & 11.6 & 5.6 & 1.6 & 0.6 \\
\hline
\end{tabular}

An especially interesting finding was that the space for parking and access seems to have stayed very stable over time. When investigated in more detail in relation to building year and type (Table 2), the data showed that parking on the premises increased over time for "New permanent" kindergartens. "Rehabilitated" and extended kindergartens had to comply with current laws for parking, and it seems that parking on these premises had decreased, although this was not statistically significant. By adding "New permanent" and "Rehabilitated" kindergartens together, the results were as follows: $1975-2006=47.9 \%$ (45 of 94) and after $2006=48.9 \%$ ( 22 of 45 ) had parking on the premises. The proportion of kindergartens with parking was thus similar for the two time periods, with an overall slight increase in the latter period. "Temporary pavilions" were exempted from the requirement of parking.

Table 2. Per cent of kindergartens with parking on the premises $(\mathrm{N}=201)$ in relation to year and type

\begin{tabular}{l|c|c|c|c}
\hline Year & $\begin{array}{c}\text { New permanent } \\
\%(N)\end{array}$ & $\begin{array}{c}\text { Rehabilitated } \\
\%(N)\end{array}$ & $\begin{array}{c}\text { Temporary pavilions } \\
\%(N)\end{array}$ & $\begin{array}{c}\text { Total } \\
\%(N)\end{array}$ \\
\hline Before 1975 & $25.6(10$ of 39$)$ & - & - & $25.6(10$ of 39$)$ \\
\hline $1975-2006$ & $45.1(37$ of 82$)$ & $66.7(8$ of 12$)$ & $0.0(0$ of 5$)$ & $45.5(45$ of 99$)$ \\
\hline After 2006 & $48.1(13$ of 27$)$ & $50.0(9$ of 18$)$ & $0.0(0$ of 18$)$ & $34.9(22$ of 63$)$ \\
\hline
\end{tabular}

Was there a relationship between "Play area" and "Parking"? Table 3 presents how kindergartens with parking on the premises and play area over a norm of $24 \mathrm{~m}^{2}$ relate to available remaining space over time. A previous study by Nilsen \& Hägerhäll (2012) compared kindergartens built before and after the time period when a norm of $24 \mathrm{~m} 2$ play space per child was present. There seemed to be a link between parking and play area: "Parking" has increased while "Play area" has decreased. The table shows that the more remaining space available, the larger the portion of kindergartens that had allocated parking space on the premises. With no remaining space, parking cannot be on the premises, showing 
$0 \%$ in all cases. In general, the number of kindergartens having play area over the norm has decreased over time.

Table 3. Per cent of kindergartens with parking on the premises and play area over norm of $24 \mathrm{~m}^{2}$ per child, in relation to size of administrative space and building year $(\mathrm{N}=178$; temporary pavilions not included)

\begin{tabular}{|c|c|c|c|c|c|}
\hline \multirow[t]{2}{*}{ Parking } & \multicolumn{4}{|c|}{ Administrative space } & \multirow{2}{*}{$\begin{array}{l}\text { Total } \\
\%(M)\end{array}$} \\
\hline & $\begin{array}{l}0 \mathrm{~m}^{2} \\
\%(M)\end{array}$ & $\begin{array}{c}1-299 \mathrm{~m}^{2} \\
\%(M)\end{array}$ & $\begin{array}{c}300-599 \mathrm{~m}^{2} \\
\%(N)\end{array}$ & $\begin{array}{c}600+m^{2} \\
\%(M)\end{array}$ & \\
\hline \multicolumn{6}{|l|}{ Before 1975} \\
\hline Parking & $0.0 \quad(0$ of 10$)$ & $16.7(1$ of 6$)$ & 16.7 (1 of 6$)$ & $47.1(8$ of 17$)$ & $25.6(10$ of 39$)$ \\
\hline Over norm & $100.0(10$ of 10$)$ & $100.0(6$ of 6$)$ & $50.0(3$ of 6$)$ & 82.4 (14 of 17$)$ & 84.6 (33 of 39 ) \\
\hline \multicolumn{6}{|l|}{ 1975-2006 } \\
\hline Parking & $0.0(0$ of 11$)$ & 25.0 (7 of 27$)$ & 50.0 (13 of 26$)$ & $83.3(25$ of 30$)$ & 47.9 (45 of 94$)$ \\
\hline Over norm & 81.1 (9 of 11) & 66.7 (18 of 27$)$ & $76.9(20$ of 26$)$ & $76.7(23$ of 30$)$ & $74.5(70$ of 94$)$ \\
\hline \multicolumn{6}{|l|}{ After 2006} \\
\hline Parking & $0.0(0$ of 9$)$ & $55.6(5$ of 9$)$ & 40.0 (4 of 10$)$ & 76.5 (13 of 17 ) & 48.9 (22 of 45$)$ \\
\hline Over norm & $66.7(6$ of 9$)$ & $77.8(7$ of 9$)$ & $70.0(7$ of 10$)$ & $52.9(9$ of 17$)$ & $64.4(29$ of 45$)$ \\
\hline \multicolumn{6}{|l|}{ In total } \\
\hline Parking * & $0.0(0$ of 30$)$ & 31.0 (13 of 42$)$ & 42.9 (18 of 42$)$ & $71.9(46$ of 64$)$ & $43.3(77$ of 178$)$ \\
\hline Over norm ** & $83.3(25$ of 30$)$ & 73.8 (31 of 42$)$ & $75.0(30$ of 40$)$ & $71.9(46$ of 64$)$ & 74.2 (132 of 178$)$ \\
\hline
\end{tabular}

${ }^{*}(X 2(3, N=178)=46.818, p=.000){ }^{* *}(X 2(3, N=178)=1.659, p=.646)$

\section{Discussion}

The aim of this study was to investigate how the utilization of outdoor space corresponded to changes in applied norms and law over time. The hypothesis was that some needs were better protected by law and norms, causing the play area for children to decrease, and the results indicated that this was the case. Reduction in play area comprised more than $50 \%$ of the total reduction of gross size per child on each property in average. The area for parking and car access was practically not reduced at all, indicating better protection and firmer requirements than for play space.

When the regular planning of kindergarten became an integrated part of city planning in the 1950s, space for parking was not an issue. New kindergartens were planned for a designated neighbourhood and were integrated in such a way that parents and children were meant to walk there. In the 1960 s, cars were made available to the private consumer, and the car began to be a natural part of family life in the 70s. From then on, children and employees have been more likely to arrive at kindergarten by car. Another reason for the current need for parking at kindergartens is that children are not automatically granted a kindergarten place within walking distance from their home, due to varying coverage across the city, resulting in a need for many parents to take their child perhaps even to a neighbouring borough, and the car is often a more convenient option than public transport.

All kindergartens in the outer city of Oslo must comply with parking requirements according to the number of employees and visitors they have. However, in the material on 201 kindergarten premises, 124 had no parking on the premises. Except for new temporary pavilions, which were exempt from the requirement, all other premises had to comply with the requirement. This was solved by locating parking on nearby premises. Finding all the relevant parking lots turned out to involve too high a workload, and was not within the scope of this study. The fact that $50 \%$ of kindergartens had parking on a neighbouring site can be explained by planners going to great lengths to avoid meeting the parking requirement at the expense of play area. However, this did not seem to compensate for all the loss of play area within the kindergartens. The history of this situation began in 1973, when the first norms for parking downtown and in the inner city of Oslo were implemented, but these did not specify requirements concerning kindergartens (Oslo byplankontor, 1973). In 1983, a parking norm 
requiring one to three car parking places per ten employees and two to three guest car parking places was implemented, for both the inner and outer city (Plan- og bygningsetaten, 1989). This norm was updated in 1985 and 2004, and today requires two to six car parking places per ten employees in the outer city (Plan- og bygningsetaten, 2004). The need for guest parking is evaluated if necessary.

As documented in a previous study (Nilsen \& Hägerhäll, 2012), no legal requirements for play space in kindergartens existed after 2006 in Norway; a norm requiring $24 \mathrm{~m}^{2}$ per child was only present from 1975 to 2006 . Given the strong international acknowledgement of children's right and need to play, and the reported protective effect of norms, what could the arguments be for removing this norm? One reason could be a belief that an increased freedom for planners to adapt to local needs and physical situations would actually allow for more efficient planning, according to the theory of New Public Management. At least this was an argument in the Norwegian case concerning kindergartens' adaptation to local conditions, when it was suggested that the fixed requirement for play area per child be removed (MER, 2005).

As shown in Table 1, there has been a general decrease in gross size per child in kindergartens over time. Other large reductions in area were observed for "Unused" space with about $15 \%$, and "Footprint of buildings" with about $12 \%$.

The area used for parking and roads per child was almost unchanged during the three time periods. Table 2 shows that the more remaining space available, the larger the portion of kindergartens that had allocated parking space on the premises. This is an expected finding, as the parking requirements are not to be deviated from. The Municipal Undertaking for Social Service Buildings always plans parking using the minimum standard required in the parking guidelines. The outer city has an open structure, and many children arrive at kindergarten by car. New kindergartens are therefore given solutions for effectively dropping off children without having to park, often called "kiss and drive", along pavements in addition to regular parking spaces for employees on the premises. However, it often happens that neighbours require that all access and parking is solved entirely on the kindergarten premises. Neighbours want their residential streets safer and easily accessible at all times. The main reason for the reduction in play area thus seems to be that a larger proportion of kindergartens built before 1975 had no parking on the premises; among these, the average play area was larger.

A larger per cent of permanent kindergartens built after 2006 than those built before had parking on the premises. It is of special interest to find that no temporary pavilions had parking on the premises (see Table 2). It seems that either temporary pavilions were granted exemption from the parking requirements in all cases, or the parking issue was solved on adjacent property or by using already existing parking. Many pavilions have been located near green structures and share their parking facilities with entrances to recreation areas, also governed by the city of Oslo. All temporary pavilions were made permanent by an agreement by the city board in 2010 .

On the other hand, rehabilitated kindergartens have not been able to be exempted from the parking requirement, but must have been asked to update the parking area according to current norm.

In Table 3, one can find a decrease in parking after 2006 on premises with remaining space between 300 and $599 \mathrm{~m}^{2}$ as well as for those with larger remaining space. This decline might be explained by the location of new kindergartens, focusing on facilitating the use of public transport. A successful location is one that allows parents to choose public transport for dropping off and picking up their children. Another possible explanation is that limited parking space forces parents to arrive by public transport instead. 
The results for the variable "Unused" (see Table 1) are somewhat surprising. Compared with buildings with absolute requirements for space efficiency, they reveal a lost possibility to add to the play area.

The results of this study show that three of 12 variables seemed to be possible for the landscape architect to change or negotiate, while the following eight are required by law and can therefore be described as non-negotiable: "Footprint of buildings", "Parking and access", "Corridors", "Roadside", space areas set aside for "Safety" reasons or for protection from "Noise", "Fire" and "Radiation". The "Gross size", or use of the overall property, is negotiable until zoning is decided, but must be regarded as non-negotiable at the stage in the planning process during which the landscape architect participates. Landscape architects are apparently not able to hinder the decreasing in play area size per child. Allowing the landscape architects to participate at an earlier stage in the planning process is not likely to change the trend. Also architects planning at this stage must relate to the same sets of negotiable and non negotiable variables. The most effective solution would probably be to implement a minimum size requirement per child defined by law.

Only three of the discussed variables were negotiable: "Play area" after 2006, "Unused" space and "Waste storage" (the size of the waste storage was somewhat negotiable based on the possibility to pay for frequent collection; low frequency is cheaper, but requires more room for storage). These variables may be seen as space reservoirs when other nonnegotiable variables were in need of more space. "Play area" was the most abundant of the three variables.

One can assume that the law has been formulated according to requirements for the protection of necessary functions and the implementation and protection of functional requirements. Structural requirements and the regulation of parking, access and traffic seem to have been formulated and prioritized to a much greater extent than the need for play space. One can argue that the "victory" in the space rival discourse goes to non-negotiable variables. Non-negotiable variables, for example a parking lot, are often materialized in a rigid nature, whereas a negotiable variable like play area is more organic and malleable in its physical nature. If all variables were non-negotiable, it would be difficult to achieve maximum utilization of space. An interesting fact is that during the years when play area was a nonnegotiable variable (between 1975 and 2006) the "Unused" space was $3.05 \mathrm{~m}^{2}$ per child, but decreased by nearly $1.5 \mathrm{~m}^{2}$ per child compared with after 2006 (see Table 1). This fact indicates that it is difficult to add physical spaces with different legal requirements without "Unused" or non-programmed space in between, giving a plausible physical reason for why play area decreased when the set requirement for play area per child was removed in 2006; thus, in reality the play area became a source for mediating other space requirements.

\section{Conclusion}

It appears that all types of remaining space have receded over time. This can be explained by a more efficient exploitation of available space in general. Parking areas increased, with the exception of the largest kindergartens, which attempted to be located near hubs of public transport. Not only gross size of land and remaining space but also play areas decreased over time, possibly causing a negative effect on the children's health, social/physical development and well being. The pressures on sites were ubiquitous. New solutions for better exploitation were found, such as increasing the number of children per plot and locating the kindergarten near public transport to avoid having to meet parking standards. However, since there was no minimum required play area size per child there is nothing that prevented this process from continuing.

The results of this study indicate that children's play area has obtained less status during the past decades, compared to parking and roads on the premises of each kindergarten. 
A possible solution to hinder the decreasing in play area size per child could be to implement a minimum size requirement per child defined by law, making play area a non-negotiable variable. To do so, more research on what size per child is sufficient should be performed. The challenge of securing a certain size per child cannot be understood as a design problem, but must be controlled and regulated by law to ensure that children's needs are met.

\section{Acknowledgment}

The work has received financial support from the Research Council of Norway. I wish to thank my supervisors, Caroline Hägerhäll and Anne-Karine Halvorsen Thorén, for their valuable input in designing the study and in preparing this report.

\section{Askild H. Nilsen}

Cand. agric.

Department of Landscape Architecture and Spatial Planning

Norwegian University of Life Sciences

E-mail: ahnilsen@gmail.com 


\section{References}

Bae, B. (2010). Realizing children's right to participation in early childhood settings: some critical issues in a Norwegian context. Early Years 30(3), 205 - 218.

Burdette, H. L., \& Whitaker, R. C. (2005). Resurrecting Free play in young children. Archives of Pediatrics and Adolescent Medicine, 159, 46-50.

Dahlgren, L. O., Sjölander, S., Strid, J. P., \& Szczepanski, A. (2007). Utomhuspedagogik som kunskapskällaNärmiljö blir lärmiljö (Outdoor education as a source of knowledge-Neighbourhood as learning environment). Lund: Studentlitteratur AB.

Dregelid, S. (2008). Ventelistene vokser (Waiting lists are expanding). Aftenposten, 25 February 2008. Retrieved from http://www.aftenposten.no/nyheter/oslo/article2276349.ece

Ellneby, Y. (1999). Om barn och stress och vad vi kan göra åt det (On children and stress and what we can do about it). Stockholm: Natur och Kultur.

Flyvbjerg, B. (2006). Five misunderstandings about case-study research. Qualitative Inquiry, 12(2), 219-245.

Gardner, H. (1998). Så tänker barn - och så borde skolan undervisa (So do children think - and so should the school teach). Falun: Brainbooks AB.

Giske, R., Tjensvoll, M., \& Dyrstad, S. M. (2010). Fysisk aktivitet i barnehagen (Physical activity in the kindergarten). Nordisk barnehageforskning, 3 (2), 53-62.

Grindberg, T., \& Langlo, J. G. (2000). Barn i bevegelse (Children in motion). Lund: Lund Studentlitteratur.

Huntsman, L. (2008). Determinants of quality in child care: A review of the research evidence. Ashfield, Australia: NSW Department of Community Services. Retrieved from http://www.community.nsw.gov.au/docswr/ assets/main/documents/research qualitychildcare.pdf

Kjørholt, A. T., \& Seland, M. (2012). Kindergarten as a bazaar: Freedom of choice and new forms of regulation. In: A. T. Kjørholt \& J. Qvortrup (Eds.), The Modern Child and the Flexible Labour Market (pp. 168185). London: Palgrave Macmillan.

Kjørholt, A. T., \& Tingstad, V. (2007). Flexible places for flexible children? Discourses on new kindergarten architecture. In: Zeiher, H., Devine, D., Kjørholt, A. T. \& Strandell, H. (Eds.) Flexible Childhood? Exploring Children's Welfare in Time and Space (pp.169-189). Odense: University press of Southern Denmark.

Mackett, R., \& Paskins, J. L. (2008). Children's Physical Activity: The Contribution of Playing and Walking. Children and Society, 22(5), 345-357.

MER (2005). Lov 17. juni 2005 nr 64 om barnehager om barnehager (The Kindergarten Act). Oslo: Ministry of Education and Research.

MER (2006). Lov av 17. juni 2005 nr 64 om barnehager (barnehageloven) med forskrifter og departementets merknader til bestemmelsene, rundskriv F-08/2006 (Act of 17 June 2005 No. 64: The Kindergarten Act and its regulations and the Ministry's comments on the regulations. Circular F-08/2006). Oslo: Ministry of Education and Research.

Nilsen, A. H., \& Hägerhäll, C. M. (2012). Impact of space requirements on outdoor play areas in public kindergartens. Nordic Journal of Architectural Research, 24(2), 8-28.

Nyhuus, S., \& Thorén, A.-K. H. (1996). Grønnstrukturens vilkår i kommunal arealplanlegging 1965-1995: endringer av grønnstrukturen i noen utvalgte by-og tettstedsområder fra 50-tallet til i dag (Conditions for the green structure in municipal area planning during 1965-1995: changes of green structure in selected urban areas from the 50's until today). Oslo: Norsk Forskningsråd.

OECD Directorate of Education. (2006). Starting Strong II. Paris: OECD Directorate of Education.

Oslo byplankontor. (1973). Parkeringsnormer i sentrum og indre sone (Parking norms in the city center and inner zone). Oslo: Agency for Planning Services.

Plan- og bygningsetaten. (1989). Parkeringsnormer i Oslo (Parking norms in Oslo) (p. 14). Oslo: Agency for Planning and Building Services.

Plan- og bygningsetaten. (2004). Parkeringsnormer for ncering og offentlige formål i Oslo (Parking norms for commercial and public purposes in Oslo) (p. 21). Oslo: Agency for Planning and Building Services. 
Powell, S. (2009). The value of play: constructions of play in government policy in England. Children and Society, 23, 29-42.

Sager, T. (2009). Planner's role: Torn between Dialogical Ideals and Neo-liberal Realities. European Planning Studies, 17(1), 65-84.

Sandborgh, G. (1982). Rörelse (Activities). Stockholm: Esselte Studium AB.

Schmidt, L. (2008). Virkemidler for bedre uterom i byboligprosjekter. Innspill til Miljøverndepartementet (No. 0801-1702) (Means for improving outdoor spaces in urban housing projects. Contributions to the Ministry of the Environment). Oslo: Ministry of Environment.

Statens forurensingstilsyn. (2005). Veileder til Miljøverndepartementets retningslinje for behandling av støy $i$ arealplanlegging (støyretningslinjen) (Vol. TA-2115/2005) (Guidelines to the policy from the Ministry of Environment for assessing noise problems in area planning). Oslo: Norwegian Pollution Control Authority.

Svedberg, L., \& Zaar, M. (1998). Boken om pedagogerna (The book about educators). Stockholm: Lieber AB.

Thorén, A.-K. H. (2003). Skolens uteareal- om behov for arealnormer og virkemidler (Outdoor space in school grounds - needs for space norms and instruments) (No. IS-1130). Oslo: Norwegian Directorate of Health and Social Affairs.

Thorén, A.-K. H., Guttu, J., \& Pløger, J. (2000). Arealnormer: Virkemiddel for livskvalitet i fysisk planlegging (Norms for space: Measures of quality of life in physical planning). Norwegian Institute for Urban and Regional Research (NIBR), 03.

UN, 2009. Convention on the Rights of the Child, General comments no. 12. New York: United Nations Organization.

Yin, R. K. (2009). Case study research: Design and methods. (Fourth Edition Vol. 5). Newbury Park, CA: SAGE Publications. 